\title{
AN ANALYSIS OF THE EXTENT TO WHICH INDUSTRY 4.0 HAS BEEN CONSIDERED IN SUSTAINABILITY OR SOCIO-TECHNICAL TRANSITIONS
}

\author{
M.M. Asiimwe ${ }^{1 * \#} \&$ I.H. de Kock ${ }^{1}$
}

\section{ARTICLE INFO}

\section{Article details}

Presented at the $30^{\text {th }}$ annual conference of the Southern African Institute for Industrial Engineering (SAIIE), held from 30 September - 2 October 2019 in Port Elizabeth, South Africa

Available online $\quad 15$ Nov 2019

\section{Contact details}

Corresponding author

17684870@sun.ac.za

\section{Author affiliations}

1 Department of Industrial Engineering, Stellenbosch

University, South Africa

\# $\quad$ Author is enrolled for an MEng (Engineering Management) in the Department of Industrial Engineering, Stellenbosch University, South Africa

DOI

http: //dx.doi.org/10.7166/30-3-2245

\section{ABSTRACT}

A growing database of literature is geared towards the analysis and evaluation of Industry 4.0. One of the points of interest is the assessment of Industry 4.0 in the context of sustainability and sustainable development. However, there seems to be a gap in the literature focusing on transitions to more sustainable states that are evidently fostered by socio-technical [system] transitions, sometimes referred to as 'sustainability transitions'. This presents the need to evaluate the interfacial layers of these disciplines, given the larger challenge of sustainability and Industry 4.0's potential to support complex problem-solving. This paper presents a bibliometric analysis of the literature that jointly considers the concepts of sustainability, sustainable development, and sociotechnical systems, and the transitions thereof with Industry 4.0.

\section{OPSOMMING}

' $n$ Groeiende databasis van literatuur is gerig op die ontleding en evaluering van Industrie 4.0. Een van die belangstellingspunte is die assessering van Industrie 4.0 in die konteks van volhoubaarheid en volhoubare ontwikkeling. Daar is egter 'n leemte in die literatuur wat fokus op die oorgang na meer volhoubare toestande wat klaarblyklik deur sosio-tegniese [stelsel] oorgange bevorder word (soms 'volhoubare oorgange' genoem). Daar is dus 'n behoefte aan die evaluering van die grensvlakke van hierdie vakgebiede, gegewe die groter uitdaging van volhoubaarheid en die potensiaal van Industrie $4.0 \mathrm{om}$ ingewikkelde probleemoplossing te ondersteun. Hierdie artikel bied ' $n$ bibliometriese analise van die literatuur wat gesamentlik die konsepte van volhoubaarheid, volhoubare ontwikkeling en sosio-tegniese stelsels en die oorgange daarvan met Industrie 4.0 bespreek.

\section{INTRODUCTION}

The modern world is rapidly advancing technologically, socially, and economically. Consequently, the concept of sustainability is increasingly prominent and necessary. Today, sustainability is broadly applied to multiple fields in an effort to ensure equitable economic growth, environmental conservation, and social prosperity for all. The term 'sustainable development' (SD) encompasses three distinct criteria - environment, economy, and society - that are the focus of sustainability [1]. The concepts of 'socio-technical systems' and 'socio-technical transitions' are strongly related to the concepts of 'sustainability' and 'sustainable development'. Socio-technical systems (STSs), as described by Sorrel [2], are the "dominant technologies, infrastructures, industries, supply chains and organisations responsible for delivering a societal function". This inevitably implies that these systems integrate the human, social, and technical factors in systems, structures, and organisational designs [3].

Incremental and aggregated socio-economic and ecological needs inherently influence the makeup of socio-technical systems. These include the external landscape needs within which these systems exist, the impact of new innovations and technologies, and emerging sustainability issues [2]. Given 
the various needs within socio-technical systems, transitions commonly referred to as 'sociotechnical transitions' (STTs) are the sustainable progression. STTs are large-scale transformations of (unsustainable) socio-technical systems and involve long-term processes and shifts to 'newer' sustainable socio-technical configurations. Transition studies assume that transition processes towards sustainable socio-technical systems inevitably result in sustainable futures. In this context, STTs are sometimes interchangeably referred to as 'sustainability transitions' (ST) [2], [4].

The Fourth Industrial Revolution (also known as 'Industry 4.0') is bringing about major shifts in the global landscape. This revolution seeks to connect resources, services, products, and human beings in real time through digitalisation and digitisation [5]. Thus it is predicted that there will be major impacts on sustainability and on its transitions as result of the shift towards the application of technologies and concepts in this paradigm [4].

Different examples in the literature highlight a variety of perspectives and links between sustainability or sustainable development and Industry 4.0. For example, these include views of Industry 4.0 as a driver of sustainability, and thus sustainability as an incentive for its expansive implementation [5], [6], [7], [8], [9]; links between Industry 4.0 and sustainability in the context of the social, economic, and ecological dimensions of sustainability [5], [10], [11]. In relation to industry, several studies relate Industry 4.0 to the sustainability of processes, technologies, and whole industries [12], [11], [13]-[16]. Although there is a growing database of literature examining the impacts of Industry 4.0 on sustainability and sustainable development, and vice versa, the question that arises is about the extent to which the transitions towards sustainable states have been considered and examined in the literature in regard to Industry 4.0.

With a growing societal awareness of technological effects, increasing ecological and resource depletion, and an increasing industrial drive towards profitability, there is strong practical and theoretical relevance in the study of the interconnectedness of people, technologies, and resources [8], [17], [18]. Despite the growing anticipation for the predicted benefits of Industry 4.0, there is considerable uncertainty among various practitioners about the implications of the shift [18]. It is essential for the various domains that apply Industry 4.0 technologies to understand the underlying dynamics of interconnectedness. STSs inherently incorporate, structure, and provide a platform to explore and understand these dynamics [2]. Therefore, an examination of such dynamics and of the shift towards more sustainable states is imperative in laying the groundwork for efforts to meet sustainability and sustainable development goals. As such, research that focuses on analysing the extent to which concepts are jointly considered plays an important role in contributing to the qualitative analysis by demystifying the links between the concepts with the ultimate aim of identifying opportunities and laying the groundwork for further research.

This paper aims to examine the extent to which concepts of Industry 4.0, sustainability, and sociotechnical systems have been jointly considered in the literature. The paper specifically analyses the literature on sustainability transitions (or socio-technical transitions). It seeks, therefore, to answer the following questions:

1. To what extent have sustainability, sustainable development, and socio-technical systems been jointly considered with Industry 4.0 in the literature?

2. Have socio-technical transitions or sustainability transitions been considered within the same context? If so, to what extent?

3. What key findings or inferences can be made from the existing body of literature dealing with these concepts?

This study aims to highlight opportunities for future research within the space of socio-technical transitions or sustainability transitions, given the advent of Industry 4.0. The paper is structured as a bibliometric analysis that presents the literature obtained, with key highlights and findings. Section 1 is the introduction of the paper, while Section 2 presents the methodology. In Section 3 results are presented, as well as inferences made. Thereafter, observed gaps and implications for possible future research are discussed in Section 4.

\section{APPROACH/METHODOLOGY}

For the purposes of this study, the literature pertaining to the concepts of sustainability and sustainable development, socio-technical systems and transitions, sustainability transitions and 
Industry 4.0 was collected using SCOPUS. Search terms, where applicable, included known variations of the term to ensure a comprehensive search. Table 1 below shows the different search variations of the terms employed.

Table 1: Search term variations where applicable

\begin{tabular}{|l|l|}
\hline Term & Variations \\
\hline Socio-technical & Sociotechnical; socio technical; socio-technical \\
\hline Transition & Transition(s)/Transformation(s) \\
\hline Industry 4.0 & Fourth Industrial Revolution; Industry 4.0; $4^{\text {th }}$ Industrial Revolution; 14.0 \\
\hline
\end{tabular}

Searches were done using combinations of sustainability and socio-technical terms with Industry 4.0. This yielded five search categories that were each given a label, as shown in Table 2 below:

Table 2: Search combinations and categories

\begin{tabular}{|c|c|c|c|c|c|}
\hline Searches & 1 & 2 & 3 & 4 & 5 \\
\hline Socio-technical systems & $\mathbf{x}$ & & & & \\
\hline Sustainability or sustainable development & & $\mathbf{x}$ & & & \\
\hline Socio-technical transition(s)/transformation(s) & & & $\mathbf{x}$ & & $\mathbf{x}$ \\
\hline Sustainability transition(s)/transformation(s) & & & & $\mathbf{x}$ & $\mathbf{x}$ \\
\hline \multicolumn{6}{|c|}{ AND } \\
\hline Industry 4.0 & $\mathbf{x}$ & $\mathbf{x}$ & $\mathbf{x}$ & $\mathbf{x}$ & $\mathbf{x}$ \\
\hline Category labels & STS 14.0 & S SD 14.0 & STT 14.0 & ST 14.0 & STT ST 14.0 \\
\hline
\end{tabular}

\section{3}

\section{RESULTS}

The results obtained from the SCOPUS search are detailed in this section. For a comprehensive analysis, no exclusion or inclusion criteria were used in the initial search in order to have as much literature as possible. Section 3.1 below presents the overall search results and their analysis and inferences. Then section 3.2 focuses on the literature in the socio-technical or sustainability transitions/transformations category along with the Industry 4.0 category.

\subsection{Overall search results}

Table 3 below displays the search algorithms and the resulting document numbers from the prescribed search categories. As expected, the body of knowledge on sustainability and sustainable development in the context of Industry 4.0 is wider than in the specific categories of socio-technical systems and transitions or transformations. A closer look at the documents obtained showed that those obtained in the search categories of STT_14.0 and ST_14.0 were aggregately returned in the category STT_ST_14.0, with the exception of one unidentified document. Subsequently, the author analysed only the documents obtained in the search categories S_SD_14.0, STS_14.0, and STT_ST_14.0.

The next subsections present an overview of a comparative analysis of timelines, subject areas, and regions of publication origin between these search categories, highlighting key findings.

\subsubsection{Timeline of publications}

Figure 1 below shows a comparison of the publication years. It is evident that the literature's consideration of Industry 4.0 in sustainability, STS, and ST/STT is fairly novel. The first document was published during the $21^{\text {st }}$ century, and all output to date has a five-year timespan. This is understandable, since a quick search on Scopus shows that the concept of Industry 4.0 and its term variations, although first considered in 1985 and later in 2006, has only been consistently considered in the literature output since 2011. Furthermore, as shown in the graph, the number of the documents can be expected to increase continuously. For example; by mid-2019, just over half the number of documents released in 2018 have already been published in the sustainability and sustainable development category. There is clearly a gap in the socio-technical systems and transitions literature, as both have more than three times fewer publications. Interestingly, the transitions literature appears to be increasing more than that on parent socio-technical systems; but this may be assumed to be a result of the modern push towards sustainability. 
Table 3: Document results

\begin{tabular}{|c|c|c|}
\hline $\begin{array}{l}\text { Search } \\
\text { category } \\
\text { label }\end{array}$ & Scopus algorithm & $\begin{array}{l}\text { Number of } \\
\text { documents } \\
\text { obtained }\end{array}$ \\
\hline S_SD_14.0 & $\begin{array}{l}\text { TITLE-ABS-KEY ((sustainability OR “Sustainable Development”) AND } \\
\text { (“Industry 4.0” OR “4th Industrial Revolution” OR “Fourth Industrial } \\
\text { Revolution" OR 14.0)) }\end{array}$ & 249 \\
\hline STS_14.0 & $\begin{array}{l}\text { TITLE-ABS-KEY ((“sociotechnical *” OR “socio-technical *” OR “socio } \\
\text { technical *”) AND (“Industry 4.0" OR “4th Industrial Revolution” OR } \\
\text { "Fourth Industrial Revolution" OR 14.0)) }\end{array}$ & 42 \\
\hline STT_14.0 & $\begin{array}{l}\text { TITLE-ABS-KEY (((sociotechnical AND transition*) OR (socio AND technical } \\
\text { AND transition*) OR (socio-technical AND transition*) OR (sociotechnical } \\
\text { AND transformation*) OR (socio AND technical AND transformation*) OR } \\
\text { (socio-technical AND transformation*)) AND (“Industry 4.0” OR “4th } \\
\text { Industrial Revolution” OR “Fourth Industrial Revolution” OR “I4.0”)) }\end{array}$ & 35 \\
\hline ST_14.0 & $\begin{array}{c}\text { TITLE-ABS-KEY (((sustainability AND transition*) OR (sustainability AND } \\
\text { transformation*)) AND (“Industry 4.0” OR “4th Industrial Revolution” OR } \\
\text { "Fourth Industrial Revolution” OR “14.0”)) }\end{array}$ & 7 \\
\hline STT_ST_I4.0 & $\begin{array}{l}\text { TITLE-ABS-KEY ( ( ( sustainability AND transition* ) OR ( sustainability } \\
\text { AND transformation*) OR ( sociotechnical AND transition*) OR ( socio } \\
\text { AND technical AND transition*) OR ( socio-technical AND transition*) } \\
\text { OR ( sociotechnical AND transformation*) OR ( socio AND technical } \\
\text { AND transformation*) OR ( socio-technical AND transformation*) ) AND } \\
\text { ( "Industry 4.0" OR "4th Industrial Revolution" OR "Fourth Industrial } \\
\text { Revolution" OR "l4.0" )) }\end{array}$ & 41 \\
\hline
\end{tabular}

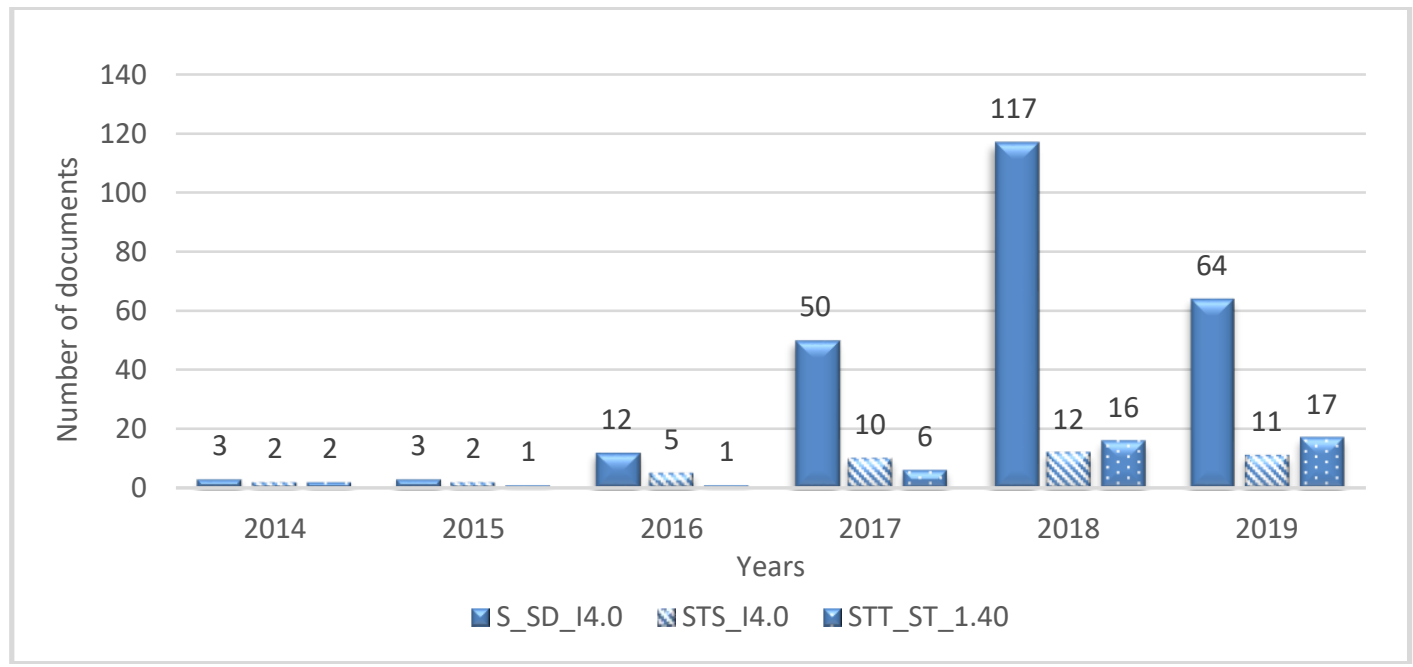

Figure 1: Documents published per year

\subsubsection{Subject areas of study}

The most common subject areas in the search categories are shown in Figure 2 below. The most common subject area overlapping all categories is engineering. The STS literature, however, has a higher output in computer science than in the sustainability/sustainable development and transitions literature. It is also noticeable that most of the literature is within the science field, with considerably less in commerce and the humanities. This may highlight a technical focus in the literature, which, although pertinent, may be well balanced by the incorporation of economic and social perspectives into the concepts. 


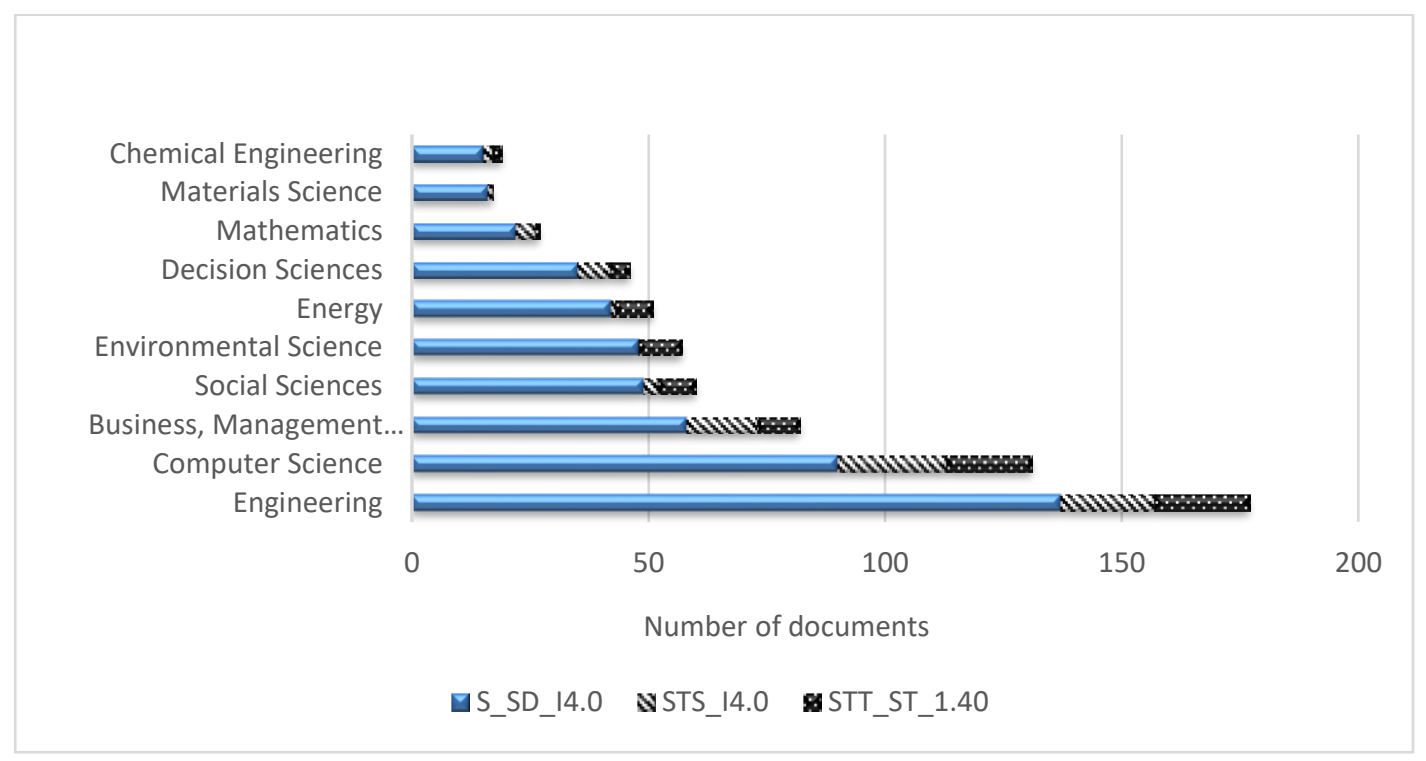

Figure 2: Subject areas of study

\subsubsection{Area of original publication}

Most of the literature found in the search categories has its origins in Europe, which has a considerably higher output than any other continent/region. This may be influenced by the output on Industry 4.0, which, from a Scopus search, is mostly from Europe - specifically, from Germany. Germany also has the highest output by country across all search categories. Nonetheless, as can be seen in Figure 3 below, there is a clear gap in the research output from other world regions, especially from Africa, the Middle East, and Oceania (Australia).

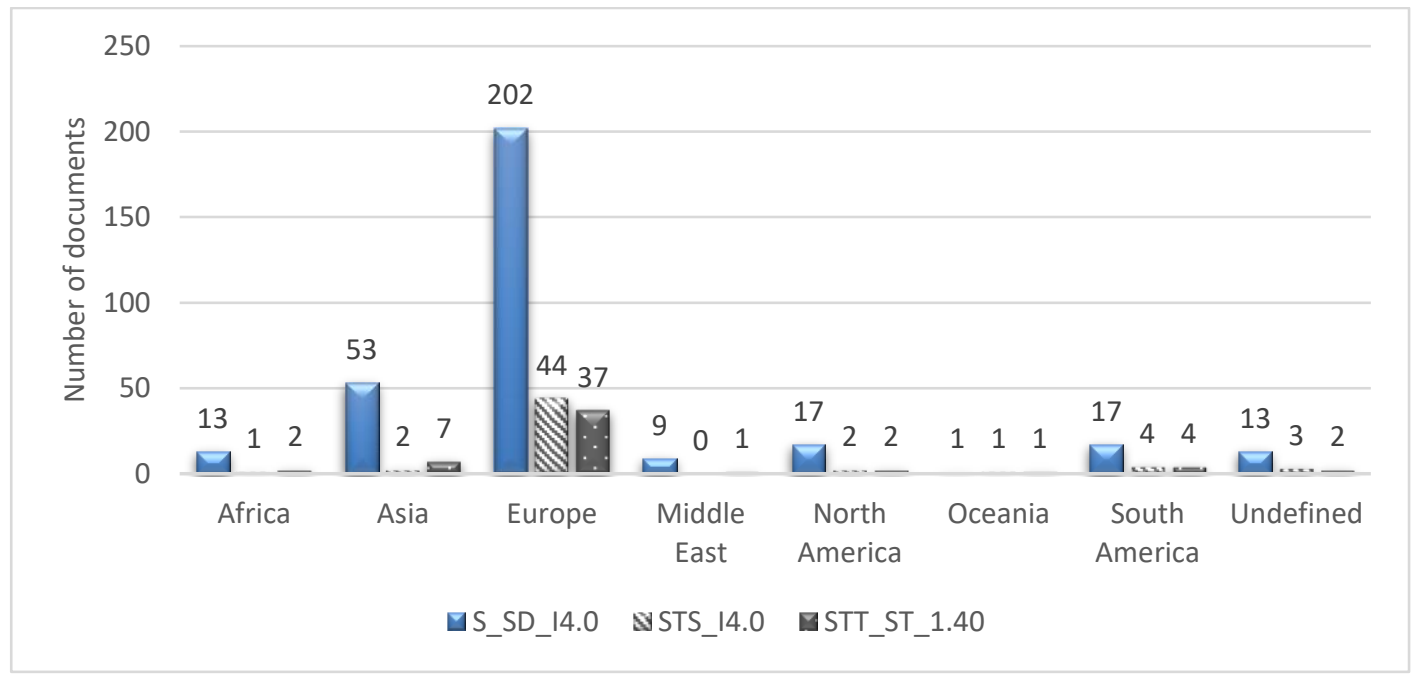

Figure 3: Documents' regions of origin

The highlights from the subsection above show that the research categories are fairly novel, have a higher traction in the science fields, and lack a comprehensive coverage in global research. The next sub-section covers the specific category of sustainability/socio-technical transitions for further insights.

\subsection{Transitions-specific descriptive analytics}

As mentioned previously, this article aims to assess the literature in the intersection between sustainability or sustainable development, socio-technical systems, and Industry 4.0 through the transitions domain. This section highlights key findings in the bibliometric analysis of the literature 
found in the STT_ST_14.0 search category for impact, prominence, and opportunities for future research.

\subsubsection{Citation and $\mathrm{H}$-index analysis}

Table 4 below shows the most cited documents in the search category, which, in this case, was all documents with at least one citation. The field-weighted citation metrics are also displayed. Given the timeline and the rate of literature output, it is understandable that the citation counts are still low. However, as can be seen, with the exception of three documents, most of them have been cited more than might be expected when compared with the global average. This shows a positive impact of the output. Furthermore, it is seen that the conference papers have had more impact than the journal articles. The documents with field-weighted citation counts higher than 10 are conference papers published in Procedia Manufacturing. This may be presumed to be linked to a combination of the widespread interest in Industry 4.0 application in manufacturing (as shown in various examples of the literature [8], [15], [19], [20], [21]) and the Procedia Manufacturing journal's relative prominence.

Table 4: Cited documents in search (Data sourced from SCOPUS)

\begin{tabular}{|c|c|c|c|c|c|}
\hline Title & Author. & Year & $\begin{array}{l}\text { Document } \\
\text { type }\end{array}$ & $\begin{array}{l}\text { Citation } \\
\text { count }\end{array}$ & $\begin{array}{l}\text { Field- } \\
\text { weighted } \\
\text { citation } \\
\text { count }\end{array}$ \\
\hline $\begin{array}{l}\text { Exploring how usage-focused } \\
\text { business models enable circular } \\
\text { economy through digital } \\
\text { technologies [22] }\end{array}$ & $\begin{array}{l}\text { Bressanelli G., } \\
\text { Adrodegari F., } \\
\text { Perona M., Saccani } \\
\text { N. }\end{array}$ & 2018 & Article & 12 & 6.40 \\
\hline $\begin{array}{l}\text { A cross-strait comparison of } \\
\text { innovation policy under Industry } 4.0 \\
\text { and sustainability development } \\
\text { transition [23] }\end{array}$ & $\begin{array}{l}\text { Lin K.C., Shyu J.Z., } \\
\text { Ding K. }\end{array}$ & 2017 & Article & 11 & 2.33 \\
\hline $\begin{array}{l}\text { Learning factories' trainings as an } \\
\text { enabler of proactive workers' } \\
\text { participation regarding Industrie } \\
4.0[24]\end{array}$ & $\begin{array}{l}\text { Reuter M., Oberc } \\
\text { H., Wannöffel M., } \\
\text { Kreimeier D., } \\
\text { Klippert J., Pawlicki } \\
\text { P., Kuhlenkötter B. }\end{array}$ & 2017 & Article & 9 & 1.79 \\
\hline $\begin{array}{l}\text { Industry } 4.0 \text { as enabler for a } \\
\text { sustainable development: A } \\
\text { qualitative assessment of its } \\
\text { ecological and social potential [25] }\end{array}$ & $\begin{array}{l}\text { Stock T., Obenaus } \\
\text { M., Kunz S., Kohl H. }\end{array}$ & 2018 & Article & 8 & 4.30 \\
\hline $\begin{array}{l}\text { Sustainability impact of digitization } \\
\text { in logistics [19] }\end{array}$ & Kayikci Y. & 2018 & $\begin{array}{c}\text { Conference } \\
\text { paper }\end{array}$ & 6 & 16.17 \\
\hline $\begin{array}{l}\text { Exploring gamification to support } \\
\text { manufacturing education on } \\
\text { Industry } 4.0 \text { as an enabler for } \\
\text { innovation and sustainability [26] }\end{array}$ & $\begin{array}{l}\text { Paravizo E., Chaim } \\
\text { O.C., Braatz D., } \\
\text { Muschard B., } \\
\text { Rozenfeld H. }\end{array}$ & 2018 & $\begin{array}{c}\text { Conference } \\
\text { paper }\end{array}$ & 5 & 13.47 \\
\hline $\begin{array}{l}\text { Smart factory implementation and } \\
\text { process innovation: A preliminary } \\
\text { maturity model for leveraging } \\
\text { digitalization in manufacturing [27] }\end{array}$ & $\begin{array}{l}\text { Sjödin D.R., Parida } \\
\text { V., Leksell M., } \\
\text { Petrovic A. }\end{array}$ & 2018 & Article & 4 & 2.52 \\
\hline $\begin{array}{l}\text { Cooperation in } \mathrm{R} \& \mathrm{D} \text { and eco- } \\
\text { innovations: The role in companies' } \\
\text { socioeconomic performance [28] }\end{array}$ & $\begin{array}{l}\text { Tumelero C. Sbragia } \\
\text { R., Evans S. }\end{array}$ & 2019 & Article & 3 & 4.94 \\
\hline $\begin{array}{l}\text { Industry 4.0: Sustainable material } \\
\text { handling processes in industrial } \\
\text { environments [29] }\end{array}$ & $\begin{array}{l}\text { Bechtsis D., Tsolakis } \\
\text { N., Vouzas M., } \\
\text { Vlachos D. }\end{array}$ & 2017 & $\begin{array}{c}\text { Book } \\
\text { chapter }\end{array}$ & 3 & 3.65 \\
\hline
\end{tabular}




\begin{tabular}{|c|c|c|c|c|c|}
\hline Title & Author. & Year & $\begin{array}{c}\text { Document } \\
\text { type }\end{array}$ & $\begin{array}{l}\text { Citation } \\
\text { count }\end{array}$ & $\begin{array}{l}\text { Field- } \\
\text { weighted } \\
\text { citation } \\
\text { count }\end{array}$ \\
\hline $\begin{array}{l}\text { The paradigms of Industry } 4.0 \text { and } \\
\text { circular economy as enabling } \\
\text { drivers for the competitiveness of } \\
\text { businesses and territories: The case } \\
\text { of an Italian ceramic tiles } \\
\text { manufacturing company [30] }\end{array}$ & $\begin{array}{l}\text { Garcia-Muiña F.E., } \\
\text { González-Sánchez } \\
\text { R., Ferrari A.M., } \\
\text { Settembre-Blundo } \\
\text { D. }\end{array}$ & 2018 & Article & 3 & 4.34 \\
\hline $\begin{array}{l}\text { Development of the DGQ role } \\
\text { bundle model of the Q occupations } \\
\text { [31] }\end{array}$ & $\begin{array}{l}\text { Schlüter N., } \\
\text { Sommerhoff B. }\end{array}$ & 2017 & Article & 2 & 0.87 \\
\hline $\begin{array}{l}\text { Smart industry and the pathways to } \\
\text { HRM 4.0: Implications for SCM [32] }\end{array}$ & $\begin{array}{l}\text { Liboni L.B., } \\
\text { Cezarino L.O., } \\
\text { Jabbour C.J.C., } \\
\text { Oliveira B.G., } \\
\text { Stefanelli N.O. }\end{array}$ & 2019 & Review & 2 & 1.91 \\
\hline $\begin{array}{l}\text { Ergonomics and design in Industry } \\
4.0[33]\end{array}$ & Laudante $\mathrm{E}$. & 2017 & $\begin{array}{l}\text { Conference } \\
\text { paper }\end{array}$ & 1 & 0.86 \\
\hline $\begin{array}{l}\text { Socio-technical considerations for } \\
\text { the use of blockchain technology in } \\
\text { healthcare [34] }\end{array}$ & $\begin{array}{l}\text { Wong M.C., Yee } \\
\text { K.C., Nøhr C. }\end{array}$ & 2018 & $\begin{array}{c}\text { Conference } \\
\text { paper }\end{array}$ & 1 & 3.31 \\
\hline $\begin{array}{l}\text { Transformative sustainable business } \\
\text { models in the light of the digital } \\
\text { imperative - a global business } \\
\text { economics perspective [35] }\end{array}$ & Brenner B. & 2018 & Review & 1 & 0.46 \\
\hline $\begin{array}{l}\text { Technology usage, expected job } \\
\text { sustainability, and perceived job } \\
\text { insecurity [36] }\end{array}$ & Nam T. & 2019 & Article & 1 & 3.23 \\
\hline $\begin{array}{l}\text { Development of a risk framework } \\
\text { for Industry } 4.0 \text { in the context of } \\
\text { sustainability for established } \\
\text { manufacturers [37] }\end{array}$ & $\begin{array}{l}\text { Birkel H.S., Veile } \\
\text { J.W., Müller J.M., } \\
\text { Hartmann E., Voigt } \\
\text { K.-I. }\end{array}$ & 2018 & Article & 1 & 3.15 \\
\hline $\begin{array}{l}\text { A holonic framework for managing } \\
\text { the sustainable supply chain in } \\
\text { emerging economies with smart } \\
\text { connected metabolism [38] }\end{array}$ & $\begin{array}{l}\text { Martín-Gómez A., } \\
\text { Aguayo-González } \\
\text { F., Luque A. }\end{array}$ & 2019 & Article & 1 & 3.17 \\
\hline $\begin{array}{l}\text { Exploring Industry } 4.0 \text { technologies } \\
\text { to enable circular economy } \\
\text { practices in a manufacturing } \\
\text { context: A business model proposal } \\
\text { [39] }\end{array}$ & $\begin{array}{l}\text { Nascimento D.L.M., } \\
\text { Alencastro V., } \\
\text { Quelhas O.L.G., } \\
\text { Caiado R.G.G., } \\
\text { Garza-Reyes J.A., } \\
\text { Lona L.R., } \\
\text { Tortorella G. }\end{array}$ & 2019 & Review & 1 & 2.34 \\
\hline
\end{tabular}

Unfortunately, at this stage it is difficult to tell whether there are any strong correlations between document type, journal prominence, topic interests, and document impact, due to the short time span. This is exemplified, for example, in the worst-performing field-weighted citation count documents, as they include a conference paper presented at the International Conference on Sustainable Smart Manufacturing 2016 (which would presumably have a manufacturing focus in the context of Industry 4.0) and a review published in Sustainability (Switzerland), which is the most prominent journal in this category based on the citations shown in Table 5.

\subsubsection{Journal comparisons}

Table 5 below displays the most prominent journals in this search, which in this case was taken as the journals with at least one citation. The most prominent journals in this search category, as shown below, are Sustainability (Switzerland) and Procedia Manufacturing, publishing five and four documents respectively and having at least 20 citations for all documents. Process Safety and Environmental Protection, however, may be regarded as having more impact on an average citation per document calculation. 
Table 5: Most prominent journals in search category

\begin{tabular}{|l|c|c|}
\hline \multicolumn{1}{|c|}{ Journal } & Number of documents & Number of citations \\
\hline 1. Sustainability (Switzerland) & 5 & 25 \\
\hline 2. Procedia Manufacturing & 4 & 20 \\
\hline 3. Process Safety and Environmental Protection & 1 & 8 \\
\hline 4. Research Technology Management & 1 & 4 \\
\hline 5. Computer Aided Chemical Engineering & 1 & 3 \\
\hline 6. Journal of Cleaner Production & 1 & 3 \\
\hline 7. Social Sciences & 1 & 3 \\
\hline 8. International Journal of Quality and Service & 1 & 2 \\
\hline Sciences & & 2 \\
\hline 10. International Conference on Sustainable Smart & 1 & 1 \\
\hline Manufacturing 2016 & 1 & 1 \\
\hline 11. Journal of Manufacturing Technology & 1 & 1 \\
\hline 12. Resources, Conservation and Recycling & 1 & 1 \\
\hline 13. Studies in Health Technology and Informatics & 1 & 1 \\
\hline 14. Technological Forecasting and Social Change & 1 & \\
\hline
\end{tabular}

A further analysis comparing the above journals against the top journals in the subject fields in the search category on Scopus revealed that none of the journals listed in Table 5 ranks in the top 10 per cent or the first quartile. However, given the novelty of the research based on timelines, there is still the potential for journals and published documents to establish their prominence as the concepts progressively gain relevance.

\subsubsection{Keyword analysis and emerging links}

To measure the co-occurrence of keywords and to determine emerging links, VOSviewer software was used. The relevant information on its use may be found in documents by Van Eck [40], [41] and the University of Rotterdam [42] This network shows all author and index keyword co-occurrence links from the literature found. For a more comprehensive picture, a minimum word occurrence of 2 was chosen, as well as a minimum link strength of 1 , which means that each keyword should have been linked with another at least once. Fifty-four keywords met the threshold, and thus are displayed in Figure 4 below. As can be seen, the network diagram created in VOSviewer colourclusters keywords according to the software's algorithm [40], [41]. Seven clusters were identified as categorising keywords, in red, green, darker blue, yellow, purple, lighter blue, and orange. Cluster descriptions are not offered by VOSviewer software, and an attempt to form descriptions for the classification by analysing cluster keyword source documents for similarities proved futile. This was because the scope of the data was limited; and, given that an algorithm runs the classification, a larger number of keywords would produce coherent cluster description results.

Nonetheless, a few noteworthy keyword categorisations were discovered, and are presented below:

1. Major overarching concepts highlighted in the keywords include Industry 4.0, sustainability, sustainable development, digital transformation, digitalisation, the triple bottom line, coevolution, innovation, circular economy, internet, and socio-technical. These concepts are related to one other through the main themes of sustainability, socio-technical systems, and Industry 4.0, and carry links within the different clusters for other emerging keywords;

2. Key industry applications include manufacturing, learning factories, production industries and systems, risk management, management practice, supply chain management, planning, logistics, and environmental technologies;

3. Industry 4.0 technologies found within keywords include Internet of Things (loT), cyber physical systems (CPS), and automation. These especially have links in the production and manufacturing applications;

4. Other disciplines and related techniques include simulation and optimisation, systems engineering, information systems, and economics; and

5. The literature output highlighted in the networks includes literature reviews, conceptual frameworks, and maturity models. 
This scope shows the variety of areas within which the integrations of sustainability and sociotechnical transitions/transformations are being considered and/or applied.

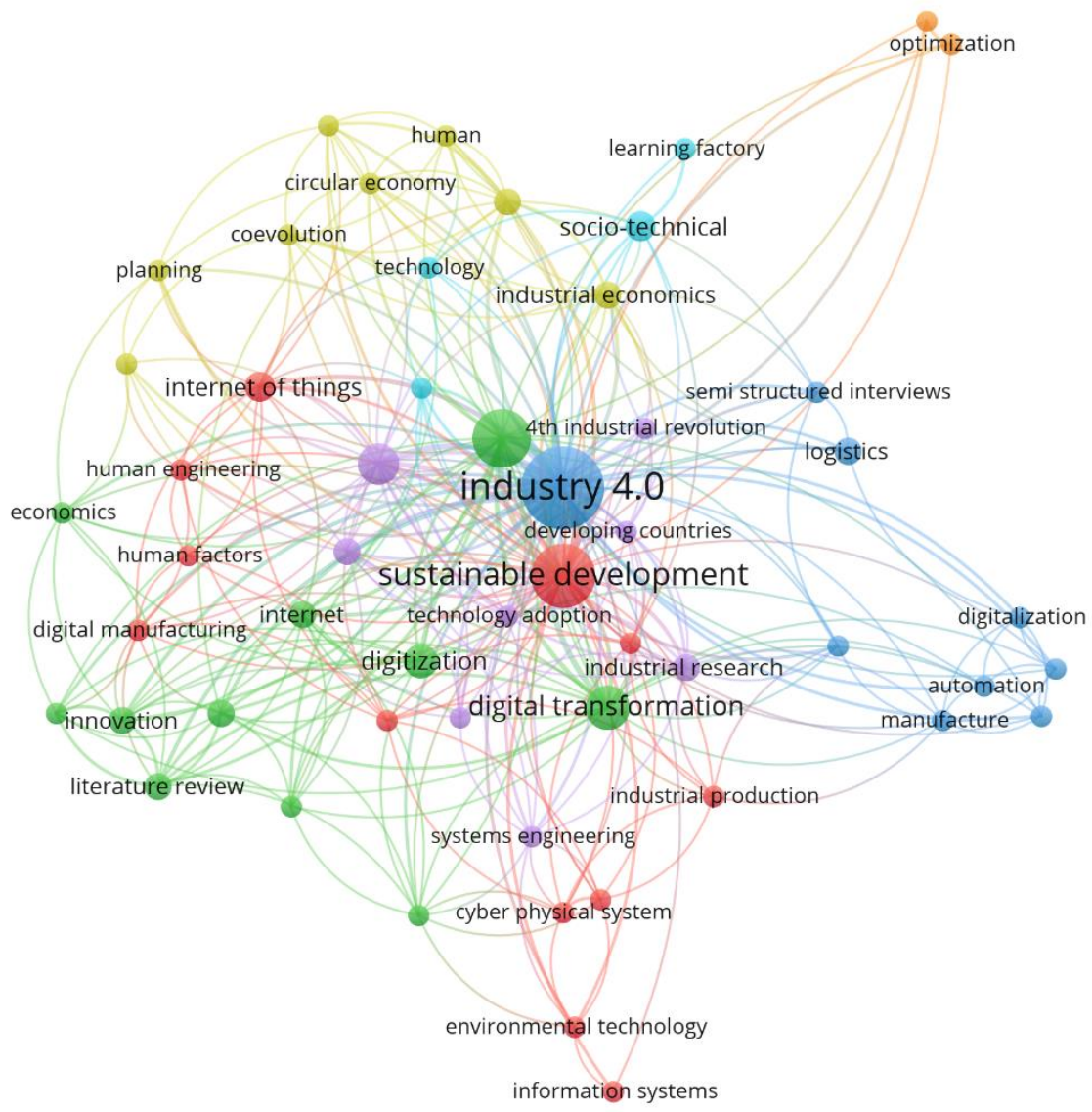

Figure 4: Keyword networks (created with VOSviewer) (see online version for colour)

\section{CONCLUSION AND OPPORTUNITIES FOR FUTURE/FURTHER RESEARCH}

The overall conclusion from this analysis is that there is a clear gap and opportunity for research that jointly considers and analyses the fields of sustainability or socio-technical transitions and Industry 4.0. The short timeline renders the field fairly novel. A lack of comprehensive coverage in the literature of regions of the world outside of Europe leaves significant opportunity for research outside that region to assess what these concepts are within their contexts, and the implications thereof. Such approaches would yield valuable additions to the body of knowledge. Furthermore, subject areas and key words show that there is great potential in overlaps within research that solely investigates the concepts of sustainability, socio-technical systems, and Industry 4.0 , as they are inter-connected. Finally, as the research on these concepts gains relevance, it can be expected that future authors and publishing journals will gain prominence in the field, which is growing.

In conclusion, this paper highlights the need for contributions to the body of knowledge on sustainability or socio-technical transitions. These findings support the further content analysis and synthesis of the existing literature to identify specific gaps and needs within the field to ensure meaningful and applicable research output.

\section{REFERENCES}

[1] Kates, R.W. Parris, T.M. et al. 2005. What is sustainable development? Goals, indicators, values, and practice. Environment: Science and Policy for Sustainable Development, 47(3), pp. 8-21. 
[2] Sorrell, S. 2018. Explaining sociotechnical transitions: A critical realist perspective. Research Policy, 47(7), pp. 1267-1282.

[3] Baxter, G. and Sommerville, I. 2011. Socio-technical systems: From design methods to systems engineering. Interacting with Computers, 23(1), pp. 4-17.

[4] Tran, M. 2014. Modeling Sustainability Transitions on Complex Networks. Complexity, 19(5), pp. 8-22.

[5] Stock, T. Obenaus, M. et al. 2018. Industry 4.0 as enabler for a sustainable development: A qualitative assessment of its ecological and social potential. Process Safety and Environmental Protection, 118, pp. 254-267.

[6] Agamuthu, P. 2017. The 4th Industrial Revolution and waste management. Waste Management and Research, 35(10), pp. 997-998.

[7] Anggusti, M. and Siallagan, H. 2018. Sustainable development in the wake of the 4th industrial revolution in Indonesia. IOP Conference Series: Materials Science and Engineering, 420(1), pp. 1-8.

[8] Habanik, J. Grencikova, A. et al. 2019. The impact of new technology on sustainable development. Engineering Economics, 30(1), pp. 41-49.

[9] Kamble, S.S. Gunasekaran, A. et al. 2018. Sustainable Industry 4.0 framework: A systematic literature review identifying the current trends and future perspectives. Process Safety and Environmental Protection, 117, pp. 408-425.

[10] de Man, J.C. and Strandhagen, J.O. 2017. An Industry 4.0 Research Agenda for Sustainable Business Models. Procedia CIRP, 63, pp. 721-726.

[11] Papetti, A. Gregori, F. et al. 2018. lot to enable social sustainability in manufacturing systems. Advances in Transdisciplinary Engineering, 7, pp. 53-62.

[12] Kiel, D. and Arnold, C. 2017. Sustainable Industrial Value Creation : Benefits and Challenges of Industry 4. 0 Julian Müller Kai-Ingo Voigt. (June), pp. 1-21.

[13] Stock, T. and Seliger, G. 2016. Opportunities of Sustainable Manufacturing in Industry 4.0. Procedia CIRP, 40(ICC), pp. 536-541.

[14] Dossou, P.E. 2018. Impact of Sustainability on the supply chain 4.0 performance. Procedia Manufacturing, 17, pp. 452-459.

[15] Carvalho, N. Chaim, O. et al. 2018. Manufacturing in the fourth industrial revolution: A positive prospect in Sustainable Manufacturing. Procedia Manufacturing, 21, pp. 671-678.

[16] Kumar, R. Singh, S.P. et al. 2018. Sustainable robust layout using Big Data approach: A key towards industry 4.0. Journal of Cleaner Production, 204, pp. 643-659.

[17] Bonilla, S.H. Silva, H.R.O. et al. 2018. Industry 4.0 and sustainability implications: A scenario-based analysis of the impacts and challenges. Sustainability (Switzerland), 10(10), pp. 1-24.

[18] Müller, J.M. Kiel, D. et al. 2018. What drives the implementation of Industry 4.0? The role of opportunities and challenges in the context of sustainability. Sustainability (Switzerland), 10(1),.

[19] Kayikci, Y. 2018. Sustainability impact of digitization in logistics. Procedia Manufacturing, 21, pp. 782 789.

[20] Nagy, J. Oláh, J. et al. 2018. The role and impact of industry 4.0 and the internet of things on the business strategy of the value chain-the case of hungary. Sustainability (Switzerland), 10(10), pp. 1-24.

[21] Rojko, A. 2017. Industry 4.0 Concept: Background and Overview. International Journal of Interactive Mobile Technologies (iJIM), 11(5), pp. 77-90.

[22] Ma, J. and Hipel, K.W. October 2016. Exploring social dimensions of municipal solid waste management around the globe - A systematic literature review. Waste Management, 56, pp. 3-12.

[23] Lin, K.C. Shyu, J.Z. et al. 2017. A cross-strait comparison of innovation policy under industry 4.0 and sustainability development transition. Sustainability (Switzerland), 9(5),.

[24] Reuter, M. Oberc, H. et al. 2017. Learning Factories' Trainings as an Enabler of Proactive Workers' Participation Regarding Industrie 4.0. Procedia Manufacturing, 9, pp. 354-360.

[25] Stock, T. Obenaus, M. et al. 2018. Industry 4.0 as enabler for a sustainable development: A qualitative assessment of its ecological and social potential. Process Safety and Environmental Protection, 118, pp. 254-267.

[26] Paravizo, E. Chaim, O.C. et al. 2018. Exploring gamification to support manufacturing education on industry 4.0 as an enabler for innovation and sustainability. Procedia Manufacturing, 21, pp. 438-445.

[27] Sjödin, D.R. Parida, V. et al. 2018. Smart Factory Implementation and Process Innovation: A Preliminary Maturity Model for Leveraging Digitalization in ManufacturingMoving to smart factories presents specific challenges that can be addressed through a structured approach focused on people, p. Research Technology Management, 61(5), pp. 22-31.

[28] Tumelero, C. Sbragia, R. et al. 2019. Cooperation in R \&amp; D and eco-innovations: The role in companies' socioeconomic performance. Journal of Cleaner Production, 207, pp. 1138-1149.

[29] Bechtsis, D. Tsolakis, N. et al. 2017. Industry 4.0: Sustainable material handling processes in industrial environments. Computer Aided Chemical Engineering, 40, pp. 2281-2286.

[30] Garcia-Muiña, F.E. González-Sánchez, R. et al. 2018. The paradigms of Industry 4.0 and circular economy as enabling drivers for the competitiveness of businesses and territories: The case of an Italian ceramic tiles manufacturing company. Social Sciences, 7(12), pp. 1-31.

[31] Schluiter, N. and Sommerhoff, B. 2017. Development of the DGQ role bundle model of the Q occupations. International Journal of Quality and Service Sciences, 9(3-4), pp. 317-330.

[32] Liboni, L.B. Cezarino, L.O. et al. 2019. Smart industry and the pathways to HRM 4.0: implications for SCM. Supply Chain Management, 24(1), pp. 124-146. 
[33] Laudante, E. 2017. Ergonomics and design in industry 4.0. Challenges for Technology Innovation: An Agenda for the Future - Proceedings of the International Conference on Sustainable Smart Manufacturing, S2M 2016, pp. 161-166.

[34] Wong, M.C. Yee, K.C. et al. 2018. Socio-technical considerations for the use of blockchain technology in healthcare. Studies in Health Technology and Informatics, 247, pp. 636-640.

[35] Brenner, B. 2018. Transformative sustainable business models in the light of the digital imperative-a global business economics perspective. Sustainability (Switzerland), 10(12),.

[36] Nam, T. 2019. Technology usage, expected job sustainability, and perceived job insecurity. Technological Forecasting and Social Change, 138, pp. 155-165.

[37] Birkel, H.S. Veile, J.W. et al. 2019. Development of a risk framework for Industry 4.0 in the context of sustainability for established manufacturers. Sustainability (Switzerland), 11(2), pp. 1-24.

[38] Martín-Gómez, A. Aguayo-González, F. et al. 2019. A holonic framework for managing the sustainable supply chain in emerging economies with smart connected metabolism. Resources, Conservation and Recycling, pp. 219-232.

[39] Nascimento, D.L.M. Alencastro, V. et al. 2019. Exploring Industry 4.0 technologies to enable circular economy practices in a manufacturing context: A business model proposal. Journal of Manufacturing Technology Management, 30(3), pp. 607-627.

[40] Van Eck, N.J. and Waltman, L. 2014. Visualizing Bibliometric Networks. in Measuring Scholarly Impact, pp. 285-320.

[41] Van Eck, N.J. and Waltman, L. 2016. VOSviewer Manual (version 1.6.4).

[42] Erasmus University Rotterdam VOSviewer Keywords map. 